\title{
Post-Coital Contraceptive Effect of 2-Br- $\alpha$-Ergocryptine (CB-154) in the Rat
}

Diencephalic dopaminergic systems appear to play a significant role in the control of the hypothalamic releasing factor (RF) mechanisms subserving anterior pituitary hormone secretion ${ }^{1-3}$. The compound $2-\mathrm{Br}-\alpha-$ ergocryptine methanesulfonate (CB-154, Sandoz, Basel), a dopaminergic receptor stimulant ${ }^{4}$, has been shown to be an effective inhibitor of pituitary prolactin secretion ${ }^{5,6}$ and an ovulation blocker ${ }^{\text {. }}$.

In view of the effect of $\mathrm{CB}-154$ on neuroendocrinereproductive events, a study was undertaken to determine the effect of this drug on pregnancy in the rat.

Materials and methods. Female Sprague-Dawley rats weighing an average of $325 \mathrm{~g}$ (range: $310-350 \mathrm{~g}$ ) were used. Animals (5/group) were caged with fertile males on the evening of proestrus. The presence of vaginal sperm the next morning was considered day 1 of assumed pregnancy. CB-154 was then administered either s.c. or orally (p.o.) from days 1-7 of pregnancy. Animals were sacrificed on day 14 of pregnancy. The number of uterine implantation sites was recorded and fetuses were examined under a dissecting microscope for the presence of teratogenic signs. The presence of at least one normal fetus was the criterion of pregnancy.

CB-154 also was evaluated for estrogenic activity by recording uterine weight in young, mature ovariectomized mice (7/group). Total dose of the drug was administered

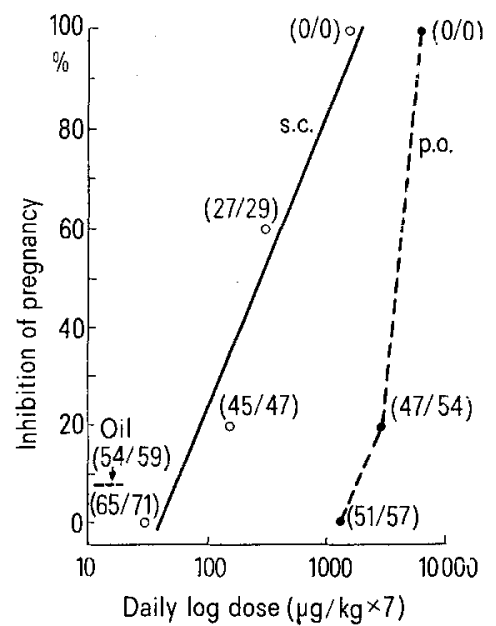

Fig. 1. Effect of CB-154 on pregnancy in the rat. Numbers in parenthesis $=$ implantation sites normal/total.

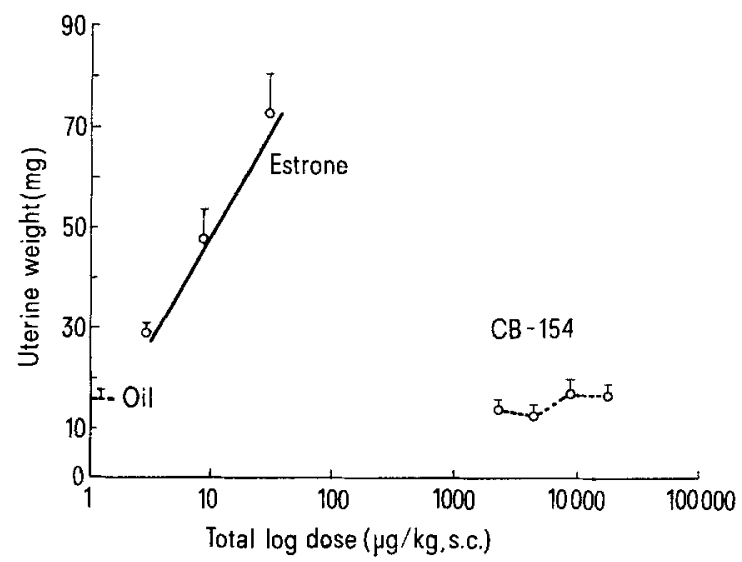

Fig. 2. Test for estrogenicity: effect of $C B-154$ on uterine weight of ovariectomized mouse. s.c. over a 3-day period; animals were sacrified the next day. Estrone was administered as a positive estrogen control.

Results and discussiou. Figure 1 demonstrates the effect of CB-154 on pregnancy in the rat. The drug is effective in inhibiting pregnancy by either the s.c. or p.o. route. The estimated minimum $100 \%$ effective daily s.c. dose is $1500 \mu \mathrm{g} / \mathrm{kg}$; that for oral treatment is $6000 \mu \mathrm{g} / \mathrm{kg}$. In the mouse estrogen test (Figure 2), CB-154 was devoid of activity. The absence of estrogenicity at post-coital contraceptive doses of $\mathrm{CB}-154$ would argue against any steroid-like effect.

In general, the ergot alkaloids have been shown to possess abortifacient and anti-implantation properties, most likely due, in part, to their oxytocic activity ${ }^{8}$.

CB-154 is a highly active cerebral dopaminergic stimulant; its ability to dramatically lower serum prolactin levels and inhibit galactorrhea is well documented ${ }^{\mathbf{9}, 10}$. The presumed mechanism is via inhibition of hypothalamic prolactin-inhibitory factor. It is tempting to speculate that CB-154's post-coital contraceptive action also is mediated via a hypothalamic system, perhaps by interfering not only with prolactin secretion, but also through a disruptive effect on luteinizing hormone RF, all of which may be necessary for corpus luteum formation, progestagen secretion and eventual maintenance of uterine integrity. However, it should be borne in mind that $\mathrm{CB}$ 154 also may act directly at the level of the anterior pituitary 11,12 .

Résumé. Le CB-154, un stimulant du récepteur dopaminergique central, administré post-coitum, pendant 7 jours, par voie s.c. ou orale, possède chez les rats une activité inhibitrice de la grossesse (en fonction de la dose) Aux doses contraceptives, Ie produit n'a aucun effet oestrogène. Les résultats suggèrent que le mécanisme hypothalamo-dopaminergique joue un rôle dans le maintien de la grossesse.

A. CORBIN

Endocrinology Section,

Wyeth Laboratories, Research Division,

Box 8299, Philadelphia (Pennsylvania 19101, USA), 10 June 1974

1 T. HÖKFELT and K. FUXE, in Brain-Endocrine Interaction, Median Eminence Structure and Function (Eds. K. M. KNIGGe, D. E. ScotT and A. Werndt; S. Karger, Base1 1972), p. 181.

${ }^{2}$ S. M. MoCann, P. S. Kalra, A. O. Donoso, W. Bishop, H. P. G. SchNeIder, C. P. FAwCETT and L. Krulich, in Brain-Endocrine Interaction, Median Eminence Structure and Function (Eds. K.M. Knigge, D. E. Scotr and A. Weinde; S. Karger, Basel 1972), p. 224.

3 A. Corbin and G. V. Upton, Experientia 29, 1552 (1973).

${ }^{4}$ H. Corrodi, K. Fuxe, T. Hökfelt, P. Lidbrinx and U. UngerSTEDT, J. Pharm. Pharmac. 25, 409 (1973).

5 E. FlüCKIGER and H. R. WAGNer, Experientia 24, 1130 (1968).

${ }^{6}$ P. MAYer and E. Schutze, Experientia 29, 484 (1973).

' M. Markó and E. Fiǘckiger, Acta endocr., Copenh., Suppl. 177 (1973), p. 138

${ }^{8}$ L. S. Goodman and A. Gilman, The Pharmacological Basis of Therapeutics (MacMillan, New York 1970).

9 E. Flückiger, P. M. Lutterbeck, H. R. Wagner and E. BilleTER, Experientia 28, 924 (1972).

${ }^{10}$ L. Varga, R. Wenner and E. Del Pozo, Am. J. Obstet. Gynec. 717, 75 (1973).

11 M. Seki, K. Seki, T. Yoshihara, N. Watanabe, T. Okumura, C. Tajtma, S.-Y. Huang and C.-C. Kuo, Endocrinology 94, 911 (1974).

12 The technical assistance of Ms. P. Dove is gratefully acknowledged. 